\title{
EVALUATION OF WATER POLLUTION STATUS IN BAHLUI RIVER (IASI TOWN AREA) DUE TO DOMESTIC AND URBAN WASTEWATER TREATMENT ACTIVITIES
}

\author{
CARMEN ZAHARIA ${ }^{1 *}$ \\ 1 "Gheorghe Asachi" Technical University of Iasi, Faculty of Chemical Engineering \\ and Environmental Protection, Department of Environmental Engineering and \\ Management, 73 Prof. Dr. Docent D. Mangeron Blvd, 700050 Iasi, Romania
}

\begin{abstract}
This study presents some data about the water pollution status of Bahlui river in Iasi town area (two control sections) mainly due to domestic and urban wastewater treatment activities, considering especially some quality indicators (i.e. nitrogen-based nutrients, total phosphorus and sum organics content) evaluated for 2009-2010. The Bahlui water classification by European standards in Iasi town area corresponds to 'medium' (WQI $=53.893$ - 64.345). The real water pollution state of Bahlui river (Iasi town area) is estimated by the global pollution index $\left(I_{G P}^{*}\right)$, and corresponds to values of 2.80-2.929 (Valea Lupului-Iasi control section), and 3.0303.196 (Holboca control section, i.e. downstream of Dancu wastewater treatment plant). These values are indicating an aquatic environment modified by domestic and urban wastewater treatment activities, generating discomfort effects, or producing stress against aquatic life forms. These data are recommending application of hydro-ameliorative/remediation actions, and permanent control of Bahlui watercourse quality in all existing control sections.
\end{abstract}

Keywords: Bahlui River, domestic activity, global pollution index, quality standard, wastewater treatment plant, water pollution status

\section{INTRODUCTION}

As a natural renewable, vulnerable and limited resource, water is considered as 'natural patrimony' that must be protected and conserved. The $21^{\text {th }}$ century is confronted with important global problems, especially of planet increasing population growth and 'drinking water crisis', among others.

The fresh water represents a very low percentage from total Earth water amount, i.e. $2.5 \%$ of Earth surface waters, but only $0.6 \%$ is directly accessible by springs, rivers, lakes, ground waters as survival resources for actual Earth population of $6.8 \times 10^{9}$ inhabitants $[1,2]$. Moreover, the total surface waters represent $97 \%$ of total estimated amount of Earth fresh waters. In addition, the fresh surface waters are enriched in biological elements, having lower mineralization referring to ground waters, and being highly influenced by different natural and human actions, easily to be polluted, but disposing of self-purification capability in some cases.

All over the world, the control of natural water resources' quality is becoming a duty or/and local environmental authority responsibility that permits the global evaluation of its pollution status mainly due to increasing constraints, and necessity of serious and more complicating water treatment for different purposes, or natural

\footnotetext{
${ }^{*}$ Corresponding author, email: $\underline{\mathrm{czah} @ \text { ch.tuiasi.ro }}$

(C) 2015 Alma Mater Publishing House
} 
conservation. Therefore, the environmental specialist opinion is extremely sensitive at challenges of future sustainable directions for natural water (NW) and/or wastewater (WW) management systems [3-11]. Local watercourses, drinking and industrial water supplies, wastewater and stormwater management represents a strict engagement of local authority for sustainability development of water management system in cities, or other appreciated tourism locations.

All domestic, sanitation or/and cleaning activities in cities can have negative impact and cause risks of environment pollution, especially of natural water resources pollution, in actual condition of fresh water deficit, or drought [2]. In this actual context, there are significant computational challenges in integrated sustainability assessment (ISA) for designing of policies, regulations and business practices for sustainable urban development $[4,12]$. The majority of these assessments are based on computational tools, more and more complicated and dependent of level dimensions, domains/fields, generations and interrelationships between its (e.g., holistic metrics-toolkits, methods and tools based on frameworks described by multi-criteria, systems' perspective and engagement of relevant stakeholders etc.). Therefore, the certification of some realities in urban productive or domestic systems concluded some disagreements between the predicted model development and real developing system status. It is also important that the environmental component (especially, environment conservation) to become a key issue in proposing sustainable developing system, mainly considering the natural water resource quality, and also its quantity and importance level. This is the reason for why the environmental impact assessment caused by the urban development due to domestic and urban WW treatment activities in the studied Romanian town is estimated by the global pollution index $\left(I^{*}{ }_{G P}\right)$, and the water quality expressed by a quality index $\left(Q I_{w}\right)$, and an environmental score $\left(E S_{w}\right)[12]$

The paper target consists in evaluating the whole domestic and urban wastewater treatment activities in period of 2009-2010 in order to follow the development strategy adopted by the local decision-makers and environmental authorities, considering environmental protection requirements in context of regional economical, technological, social and environmental development strategy, precisely sustainable development strategy. Moreover, the water resource management is involving continuous monitoring actions of water quality (depending of water bodies' importance) in different important hydrological basins of Romanian watercourses [13-16], but also diagnosis of its pollution status due to local economic (agricultural, industrial, commercial, among others) and domestic activities mainly considering the sustainable development of evaluated NE Romanian region.

The environmental impact assessment still remains one of the first stages in evaluation of sustainability of strategic development plan/program for management of a hydrological basin in a specific Romanian region [1213]. Therefore, the paper focuses on evaluation some reported data of water regional regulatory authority (National Agency 'Romanian Waters' Co. - Prut-Barlad Waters' Basin Management Division, in Romanian: A.N. Apele Romane - Administratia Bazinala a Apelor Prut-Barlad) in terms of pollution status of Bahlui River in Iasi town area (i.e. surface water quality, especially in two strategic control sections), and impact assessment of whole domestic and urban wastewater treatment activities by the global pollution index $\left(I_{G P}^{*}\right)$ in strategic control sections (i.e. $C S_{1^{-}}$Valea Lupului-Iasi area, and $C S_{2^{-}}$downstream of the local urban wastewater plant/Holboca-Iasi), for elucidation of real pollution status of Bahlui River (Iasi town area) towards the most sensible pollution receptors - the aquatic life forms, not abiotic solid media.

\section{EXPERIMENTAL SETUP}

\subsection{Characterization of Bahlui River in Iasi town area}

Bahlui River (119 km length) springs in Tudova village - Botosani county area (altitude of $500 \mathrm{~m}$ from the sea level), in Eastern part of Suceava plateau, flowing through the Inferior Jijia plain (NV-SE direction), passing through Harlau and Iasi towns, and being considered as the most important influent of Jijia River (nearly Chiperesti-Iasi). It is estimated to have an average annual flow of about $2.8 \mathrm{~m}^{3} / \mathrm{s}$, and 2,007 $\mathrm{km}^{2}$ hydrographical basin surface [15]. Its principal local influents are Gurguiata, Durusca, Ciric, Bahluet, Nicolina, Voinesti and Valea Locei considered as permanent little rivers.

Iasi town (ca 123,000 inhabitants) is surpassing by the Bahlui River (11 km length) dividing it in half. The principal districts, or residential areas in Iasi town surpassed by Bahlui river from NV to SE are: Dacia, Alexandru cel Bun, Mircea cel Batran, Podul de Piatra, Podul Ros, Tudor Vladimirescu, Gradinari and Dancu. 
The water quality of Bahlui River is periodically monitored by A.N. 'Apele Romane' Company - Prut-Barlad Waters Basin Regulatory Management Division, by analysing (daily, weekly, or monthly) some groups of quality indicators as $\mathrm{pH}$; oxygen regime: dissolved oxygen, $\mathrm{I}_{\mathrm{Mn}}, \mathrm{COD}-\mathrm{Mn} / \mathrm{CCO}-\mathrm{Cr}, \mathrm{BOD}_{5}$; mineralization level: fixed residues; nutrients' content: ammonia- $\mathrm{NH}_{4}{ }^{+}$, nitrates- $\mathrm{NO}_{2}^{-}$, nitrites- $\mathrm{NO}_{2}{ }^{-}$, total nitrogen and phosphorus, among others.

The locations of strategic control sections (named as $S C S_{i}$ ) from where were periodically sampling water for local, or/and laboratory analysis (in PE plastic, or glass recipients of 1 or $2 \mathrm{dm}^{3}$ capacity, as refrigerated, or preserved/conserved samples) $[1,2,17]$ are organized in areas with significant domestic, and urban wastewater treatment activities alongside the whole river length such as: (1) $S C S_{1}$ - Vama cu tabla, (2) $S C S_{2}-$ Av. Cotnari, (3) $S C S_{2}$ - PoduI loaiei, (4) $S C S_{4}$ - Valea Lupului-Iasi, and (5) $S C S_{5}$ - Holboca-Iasi, but only the last two strategic sections are located in Iasi town area $\left(S C S_{4}\right.$ and $\left.S C S_{5}\right)$. For appreciation of water quality in 2009-2010, there were mediated the average results registered for seasonal period (at least ten samples collected and analyzed monthly from each control section, October month), these mediated values being considered further for assessment of environmental impact due to domestic and urban wastewater treatment activities in the two investigation control sections $\left(C S_{1} \equiv S C S_{4}\right.$ and $\left.C S_{2} \equiv S C S_{5}\right)$ of Iasi town area.

\subsection{Materials and methods}

The laboratory analyses of some physical-chemical indicators, which define very well the significant impact of domestic, and urban wastewater treatment activities against the aquatic environment such as $\mathrm{pH}$, sum organics content (chemical oxygen demand-COD-Cr, and biochemical oxygen demand-BOD 5 ), total phosphorus and nitrogen-based nutrients' content were performed according with Romanian standard methods, internationally approved (SR ISO and/or SR EN), as well as the reference materials, chemical reagents, and operating parameters for spectrophotometer-based methodology, gravimetric, or volumetric methods used [17-21]: pH (SR

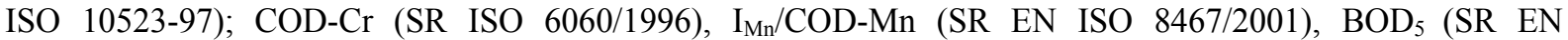
1899/2002, or SR EN 25813:2000), total phosphorus (SR EN 1189-2000), nitrates- $\mathrm{NO}_{3}{ }^{-}$(SR ISO 7890-1:1998, or SR ISO 7890-2/3:2000), nitrites-NO ${ }_{2}^{-}$(SR ISO 6777:2002, or SR EN 26777:2000), ammonia-NH ${ }^{+}$(SR ISO 5667:2001, or SR ISO 7150-1/2001), total nitrogen (SR EN ISO 13395:2002). The values of investigated physical-chemical indicators were reported by the water regulatory authority - A.N. Apele Romane Administratia Bazinala Ape Prut-Barlad, Iasi (A.B.A. Prut-Barlad), and also proper analyses of different collected samples.

\subsection{Environmental impact evaluation methodology}

There were calculated the water quality index, $Q I_{i}$ (equation 1), and also the evaluation score, $E S_{i}$, expressed by marks between 1 and 10 attributed based on evaluation scale presented in other author's works, for all considered quality indicators in this present work [12, 8-20].

$$
Q I_{i}=C_{i, \text { measured }} / M A C_{i}
$$

where $i$ - identity of quality indicator; $C_{i, \text { measured }}-$ measured value of $i$ quality indicator, and $M A C_{l}-$ maximum admissible concentration of $i$ quality indicator, or available limit of $i$ quality indicator in accordance with the imposed limits from environmental legislation, or of the local water regulatory authority.

The cumulative effect of different nutrient-based indicators (i.e. total phosphorus and nitrogen-based nutrients) together with total organics content (as food, or carbon and energy source for organisms) is expressed by the average arithmetic value (i.e. $Q I_{w}$, or $\left.E S_{w}\right)$ of all considered quality indicators $\left(Q I_{i}\right)$, or evaluation scores $\left(E S_{i}\right)$.

In the reported scientific data (based on European Standards), for the determination of the water quality index $\left(W Q I_{i}\right)$ of different studied natural water resources, it is used also the empirical equation (equation 2) $[22,23]$ :

$$
W Q I_{i}=k^{*}\left[\left(\Sigma_{i} C_{i} P i\right) / \Sigma_{i} P_{i}\right]
$$

where $k$ is a subjective constant with value between $0.25-1(0.25$ for apparent highly polluted water and 1 for apparent good quality water); $C_{i}$ is the normalized value of the $i$ quality indicator, and $P_{i}$ is the relative weight assigned to each studied and analyzed quality indicator (Table 1). 
In this present research work, such as in other studies reported in the scientific literature [22, 23], constant $k$ was not considered in order not to introduce a subjective evaluation (or it is considered as $k=1$ ). The relative weight of each water quality indicator $\left(P_{i}\right)$ is presented in Table 1.

The values of water quality index $\left(W Q I_{i}\right)$ vary in range of $0-100$, and appreciate, or estimate qualitatively the importance, and type of water quality (water classification) as: (i) very good for (90 - 100), (ii) good for (70-90), (iii) medium for (50-70), (iv) bad for (30-50), and (v) degraded, or very bad (0-30) [22, 23].

Table 1. Values of $P_{i}$ for different $i$ quality indicators of water quality.

\begin{tabular}{|l|c|c|c|c|c|c|c|c|c|c|c|}
\hline$P_{i}$ & 1 & 2 & 4 & 3 & 2 & 2 & 1 & 3 & 3 & 4 & 1 \\
\hline Indicator, $i$ & $\mathrm{pH}$ & $\mathrm{K}$ & $\mathrm{TSS}$ & $\mathrm{NH}_{4}{ }^{-}$ & $\mathrm{NO}_{2}^{-}$ & $\mathrm{NO}_{3}^{-}$ & Total & $\mathrm{COD}$ & $\mathrm{BOD}_{5}$ & $\mathrm{DO}$ & $\mathrm{T}$ \\
\hline Units & - & {$[\mathrm{S} / \mathrm{cm}]$} & {$[\mathrm{mg} / \mathrm{L}]$} & {$[\mathrm{mg} / \mathrm{L}]$} & {$[\mathrm{mg} / \mathrm{L}]$} & {$[\mathrm{mg} / \mathrm{L}]$} & {$[\mathrm{mg} / \mathrm{L}]$} & {$[\mathrm{mg} \mathrm{O}$} & $/ \mathrm{L}]\left[\mathrm{mg} \mathrm{O}_{2} / \mathrm{L}\right]\left[\mathrm{mg} \mathrm{O} \mathrm{O}_{2} / \mathrm{L}\right]$ & {$\left[{ }^{0} \mathrm{C}\right]$} \\
\hline
\end{tabular}

The environmental impact due to different domestic and wastewater treatment activities alongside Bahlui watercourse in Iasi town, evaluated mainly in the organized $C S_{1}$ and $C S_{2}$ control sections, is quantified by the global pollution index $\left(I_{G P}^{*}\right)$ (equation 3), using the alternative assessment methodology proposed by Popa et al. $[18,19]$.

$$
I_{G P}^{*}=\frac{S_{i}}{S_{r}}=\frac{100 \cdot n}{E S_{1} \cdot E S_{n}+\sum_{i=1}^{n-1} E S_{i} \cdot E S_{i+1}}=\frac{100}{\overline{E S_{w}^{2}}}
$$

where $S_{i}$ - geometrical surface of non-affected natural state (ideal state of environment, a circle with ray of 10 ), $S_{r}$ - geometrical surface of real environment state (real state, a circle with ray of $E S_{w}$ ), $n$ - number of investigated quality indicators (i.e. $\mathrm{n}=1), E S_{i}$ - the evaluation score corresponding to $i$ quality indicator, $\overline{E S}_{w}^{2}$ - average value of all values for $\left(E S_{i}\right) \cdot\left(E S_{i+1}\right)(\mathrm{i}=1,2, \ldots, \mathrm{n}-1)$ that can express finally the global evaluation score $\left(E S_{w}\right)$ of aquatic environment (Figure 1) [18-19].

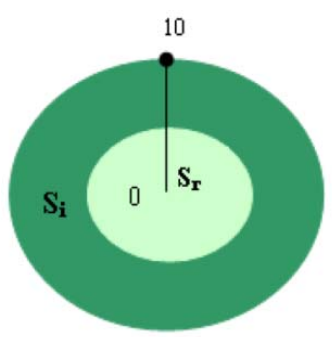

Fig. 1. Graphical representation of $I_{G P}^{*}$ alternative method: $S_{i}$ - ideal state, and $S_{r}$ - real state [18-19].

Some correlations between the global pollution index $\left(I^{*}{ }_{G P}\right)$, and real water pollution status in Bahlui River (Iasi town area) in the investigated control sections $\left(C S_{1}\right.$ and $\left.C S_{2}\right)$ are presented in Table 2 [15-20].

Table 2. Correlations $I_{G P}^{*}$ vs. water pollution status in alternative methodology of global pollution index [18-20].

\begin{tabular}{|c|l|}
\hline$I^{*}{ }_{G P}$ values & \multicolumn{1}{c|}{ Real pollution status of surface water } \\
\hline $\mathrm{I}^{*}{ }_{\mathrm{GP}}=1$ & Natural water, unaffected by all domestic and WW treatment activities \\
\hline $1<I_{G P}^{*}<2$ & Natural water modified by all domestic and WW treatment activities in admissible limits \\
\hline $2 \leq I^{*}{ }_{G P} \leq 3$ & $\begin{array}{l}\text { Natural water modified by all domestic and WW treatment, with generation of discomfort } \\
\text { effects }\end{array}$ \\
\hline $3 \leq I^{*}{ }_{G P}<4$ & $\begin{array}{l}\text { Water modified by all domestic and WW treatment activities, with stress producing against } \\
\text { life forms }\end{array}$ \\
\hline $4 \leq I_{G P}^{*}<6$ & Natural water modified by all domestic and WW treatment activities, dangerous for life forms \\
\hline$I_{G P}^{*} \geq 6$ & Polluted natural water (degraded), improper for life forms \\
\hline
\end{tabular}




\section{RESULTS AND DISCUSSION}

For the investigated watercourse (i.e. Bahlui River) in Iasi town area, the normalized (average) values of some general quality indicators are summarized in Table 3, together with its admissible legislative norms [19]. Some of these quality indicators exceeded the admissible limits, such as dissolved oxygen $\left(\mathrm{O}_{2}\right), \mathrm{BOD}_{5}, \mathrm{COD}-\mathrm{Mn}$, concentration of sulfide $\left(\mathrm{S}^{2-}\right)$ and hydrogen sulfide $\left(\mathrm{H}_{2} \mathrm{~S}\right)$, total phosphorus $(\mathrm{P})$ and phenols.

The main recognized water pollution sources of Bahlui River in Iasi town area are S.C. Antibiotice S.A. (a manufacturing plant of antibiotic drugs and medicine products), urban Dancu WW treatment plant (owned by S.C. Apa Vital S.A. Iasi, RAJAC as former company, especially because of mechanical and biological treatment stages), S.C. IASITEX S.A. Iasi (a manufacturing plant of textile fabrics and clothes), local municipal waste landfills (e.g., ( $i$ ) owned by S.C. Salubris S.A. Iasi nearly Vamasoaia, Repedea, Cacaina rivers, (ii) in av. Iasi municipality townhall, and also (iii) deposit of collected animal manures, owned by S.C. Avicola S.A. LetcaniIasi), and CET II Holboca-Iasi (a thermal power plant, using superior coal-huile, as solid fuel). Some specific pollutants, or polluting loads potentially discharged in Bahlui watercourse nearby are presented in Table 4.

Table 3. Average values of some quality indicators of Bahlui River in Iasi area (Source: A.B.A. Prut-Barlad).

\begin{tabular}{|c|c|c|c|c|c|c|c|c|c|c|c|}
\hline \multirow[b]{2}{*}{ Quality indicators } & \multirow[b]{2}{*}{ 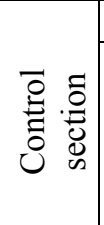 } & \multicolumn{5}{|c|}{2009} & \multicolumn{5}{|c|}{2010} \\
\hline & & $\stackrel{\Xi}{\Xi}$ & 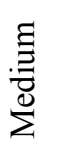 & 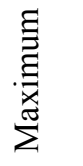 & 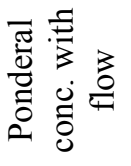 & 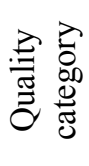 & $\underset{\sum}{\stackrel{\Xi}{\Xi}}$ & $\stackrel{\Xi}{\Xi}$ & 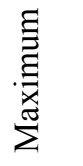 & 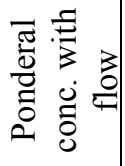 & 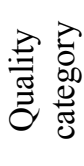 \\
\hline \multirow{2}{*}{$\begin{array}{l}\text { Temperature, } \\
{\left[{ }^{0} \mathrm{C}\right]}\end{array}$} & $C S_{1}$ & 1.1 & 12.1 & 22.3 & - & - & 0.5 & 14.2 & 24 & - & - \\
\hline & $C S_{2}$ & 3.5 & 10.3 & 25.5 & - & - & 4.3 & 17.2 & 25 & - & - \\
\hline \multirow[t]{2}{*}{$\mathrm{pH}$} & $C S_{1}$ & 8.1 & 8.3 & 8.8 & - & $\mathrm{I}$ & 8.1 & 8.4 & 9 & - & III \\
\hline & $C S_{2}$ & 7.3 & 7.7 & 8.6 & - & I & 7.9 & 8.5 & 8.7 & - & I \\
\hline \multirow{2}{*}{$\begin{array}{l}\text { Dissolved } \mathrm{O}_{2}, \\
{\left[\mathrm{mg} \mathrm{O}_{2} / \mathrm{L}\right]}\end{array}$} & $C S_{1}$ & 3.45 & 6.08 & 8.91 & 7.05 & $\mathrm{I}$ & 3.82 & 7.08 & 8.5 & 6.7 & $\mathrm{I}$ \\
\hline & $C S_{2}$ & 2.3 & 4.2 & 5.2 & 4.6 & III & 2.7 & 5.1 & 7.4 & 5.6 & III \\
\hline \multirow{2}{*}{$\begin{array}{l}\mathrm{BOD}_{5}, \\
{\left[\mathrm{mg} \mathrm{O}_{2} / \mathrm{L}\right]}\end{array}$} & $C S_{1}$ & 14.5 & 20.1 & 41.2 & 32.1 & $\mathrm{D}$ & 13.9 & 18.7 & 34 & 21.3 & $\mathrm{D}$ \\
\hline & $C S_{2}$ & 31.7 & 46.6 & 62.5 & 45 & $\mathrm{D}$ & 16 & 26.5 & 3.9 & 26 & $\mathrm{D}$ \\
\hline \multirow{2}{*}{$\begin{array}{l}\text { COD-Mn, } \\
{\left[\mathrm{mgO}_{2} / \mathrm{L}\right]}\end{array}$} & $C S_{1}$ & 21.7 & 34.4 & 54.1 & 33.1 & $\mathrm{D}$ & 20.9 & 32.7 & 45 & 35 & $\mathrm{D}$ \\
\hline & $C S_{2}$ & 39 & 49.2 & 75.4 & 50.2 & $\mathrm{D}$ & 25 & 33 & 63 & 45 & $\mathrm{D}$ \\
\hline \multirow{2}{*}{$\begin{array}{l}\text { Fixed residues, } \\
{[\mathrm{mg} / \mathrm{L}]}\end{array}$} & $C S_{1}$ & 532 & 887 & 1508 & 960 & II & 634 & 765 & 989 & 841 & II \\
\hline & $C S_{2}$ & 598 & 618 & 769 & 653 & II & 610 & 734 & 830 & 766 & II \\
\hline \multirow{2}{*}{$\begin{array}{l}\text { Chlorides, } \\
{[\mathrm{mg} / \mathrm{L}]}\end{array}$} & $C S_{I}$ & 35.2 & 58.1 & 99.6 & 64.2 & $\mathrm{I}$ & 29.7 & 35.8 & 98 & 54.8 & $\mathrm{I}$ \\
\hline & $C S_{2}$ & 43 & 76.1 & 135 & 79.2 & I & 45 & 63 & 80 & 76 & I \\
\hline \multirow{2}{*}{$\begin{array}{l}\text { Sulfates, } \\
{[\mathrm{mg} / \mathrm{L}]}\end{array}$} & $C S_{1}$ & 109 & 267 & 513 & 471 & II & 171 & 323 & 434 & 364 & II \\
\hline & $C S_{2}$ & 132 & 145 & 217 & 194 & II & 146 & 184 & 294 & 184.2 & II \\
\hline \multirow{2}{*}{$\begin{array}{l}\text { Ammonia- } \mathrm{NH}_{4}^{+}, \\
{[\mathrm{mg} / \mathrm{L}]}\end{array}$} & $C S_{1}$ & 1.32 & 1.59 & 2.71 & 1.89 & II & 1.02 & 3.34 & 4.6 & 3.42 & II \\
\hline & $C S_{2}$ & 2.97 & 4.01 & 9.95 & 6.71 & III & 3.2 & 4.21 & 11 & 5.63 & III \\
\hline \multirow{2}{*}{$\begin{array}{l}\text { Nitrites-NO }{ }_{2}^{-}, \\
{[\mathrm{mg} / \mathrm{L}]}\end{array}$} & $C S_{I}$ & 0.04 & 0.33 & 0.87 & 0.34 & $\mathrm{I}$ & 0.21 & 0.36 & 0.5 & 0.41 & $\mathrm{I}$ \\
\hline & $C S_{2}$ & 0.14 & 0.31 & 1.17 & 0.88 & $\mathrm{I}$ & 0.31 & 0.48 & 1.7 & 0.85 & $\mathrm{I}$ \\
\hline \multirow{2}{*}{$\begin{array}{l}\text { Nitrates- } \mathrm{NO}_{3}{ }^{-}, \\
{[\mathrm{mg} / \mathrm{L}]}\end{array}$} & $C S_{1}$ & 2.6 & 8.3 & 21.1 & 8.5 & I & 1.89 & 5.97 & 9.8 & 7.34 & I \\
\hline & $C S_{2}$ & 1.35 & 7.89 & 11.2 & 8.6 & $\mathrm{I}$ & 2.12 & 8.65 & 17 & 9.6 & $\mathrm{I}$ \\
\hline \multirow{2}{*}{$\begin{array}{l}\text { Phenols, } \\
{[\mathrm{mg} / \mathrm{L}]}\end{array}$} & $C S_{1}$ & 0.004 & 0.01 & 0.03 & 0.007 & $\mathrm{D}$ & 0 & 0 & 0.03 & 0.008 & II \\
\hline & $C S_{2}$ & 0.00 & 0.04 & 0.08 & 0.05 & III & 0.00 & 0.003 & 0.01 & 0.006 & II \\
\hline \multirow{2}{*}{$\begin{array}{l}\text { Total phosphorus, } \\
{[\mathrm{mg} / \mathrm{L}]}\end{array}$} & $C S_{1}$ & 0.02 & 0.34 & 0.99 & 0.57 & $\mathrm{D}$ & 0.019 & 0.219 & 0.42 & 0.229 & $\mathrm{D}$ \\
\hline & $C S_{2}$ & 0.06 & 0.39 & 0.67 & 0.48 & $\mathrm{D}$ & 0.042 & 0.53 & 2.05 & 0.656 & D \\
\hline \multirow{2}{*}{$\begin{array}{l}\text { Suspended solids, } \\
{[\mathrm{mg} / \mathrm{L}]}\end{array}$} & $C S_{I}$ & 43 & 56 & 113 & 78 & - & 25 & 184 & 713 & 322 & - \\
\hline & $C S_{2}$ & 35 & 78.5 & 178 & 96 & - & 29 & 56.5 & 176 & 127 & - \\
\hline \multirow{2}{*}{$\begin{array}{l}\text { Total hardness, } \\
{\left[{ }^{0} \mathrm{G}\right]}\end{array}$} & $C S_{1}$ & 23 & 28.9 & 35.7 & 30.1 & - & 19 & 29 & 36 & 29.1 & - \\
\hline & $C S_{2}$ & 17.5 & 23.4 & 31.2 & 28.9 & - & 18.5 & 23.8 & 33.9 & 27.8 & - \\
\hline
\end{tabular}

The statistical data reported annually by the water regulatory authority of Prut-Barlad hydrographical basin (A.B.A. Prut-Barlad) indicate that ground waters of this hydrographical basin are included in the category of 
sodium-chloride waters, or partially sodium-bicarbonate, or sodium-sulfate waters with high mineralization, presenting moderate values of organic content and fixed residue, high $\mathrm{pH}$ values, and also high total and temporal hardness values, dependent of hydrochemical characteristics of geological deposits, normal values of total iron and ammonia, but with some deviations related to maximal limits, in function of hydrogeological drilling wells' position related to pollution sources (i.e. S.C. Antibiotice S.A. Iasi, S.C. Salubris S.A., CET II Holboca-Iasi, S.C. Arcelor Mittal Tubular Products S.A. Iasi). The contamination level must be estimated in order to implement permanent control measures, and urgent remediation (if was found necessary), or environmental risk assessment.

Table 4. Principle pollution sources and specific pollutants of Bahlui River (2009-2010) [21].

\begin{tabular}{|c|c|c|c|c|}
\hline No. & Pollution Source & Emisar & Specific pollutants & Treatment degree \\
\hline 1 & $\begin{array}{l}\text { S.C. Avicola S.A. Letcani- } \\
\text { Iasi }\end{array}$ & Bahlui & $\begin{array}{l}\text { Compounds from animal manures, } \\
\text { COD-Cr, BOD } 5 \text {, suspended solids, } \\
\text { total } \mathrm{N}, \mathrm{H}_{2} \mathrm{~S}, \mathrm{CH}_{4}\end{array}$ & Not treated \\
\hline 2 & S.C. Antibiotice S.A. - CC1 & Bahlui & $\begin{array}{l}\text { Suspended solids, } \mathrm{BOD}_{5}, \mathrm{COD}-\mathrm{Cr} \text {, } \\
\text { ammonia, sulphides }\left(\mathrm{S}^{2-}\right) \text { and } \mathrm{H}_{2} \mathrm{~S}\end{array}$ & Not treated \\
\hline 3 & S.C. Antibiotice S.A. - CC2 & Bahlui & $\begin{array}{l}\mathrm{BOD}_{5} \text {, COD-Cr, suspended solids, } \\
\mathrm{H}_{2} \mathrm{~S}+\text { sulphides }\left(\mathrm{S}^{2-}\right)\end{array}$ & Not treated \\
\hline 4 & S.C. BI VA FIL S.R.L. Iasi & Bahlui & $\begin{array}{l}\text { Suspended solids, } \mathrm{BOD}_{5}, \mathrm{COD}-\mathrm{Cr} \text {, } \\
\text { ammonia, sulphides }\left(\mathrm{S}^{2-}\right)+\mathrm{H}_{2} \mathrm{~S}\end{array}$ & Insufficient \\
\hline 5 & S.C. IasiTEX S.A. Iasi & Bahlui & $\begin{array}{l}\text { Suspended solids, } \mathrm{BOD}_{5}, \mathrm{COD}-\mathrm{Cr} \text {, } \\
\text { ammonia, dyes (red-brown colored } \\
\text { ones) }\end{array}$ & Insufficient \\
\hline 6 & $\begin{array}{l}\text { S.C. Apa Vital S.A. Iasi - } \\
\text { biological and mechanical } \\
\text { steps }\end{array}$ & Bahlui & $\begin{array}{l}\text { Suspended solids, } \mathrm{BOD}_{5} \text {, COD-Cr, } \\
\text { ammonia, heavy metals, dyes (red- } \\
\text { brown color) }\end{array}$ & $\begin{array}{l}\text { Insufficient, or in- } \\
\text { correct exploitation } \\
\text { of collectors }\end{array}$ \\
\hline 7 & $\begin{array}{l}\text { S.C. Apa Vital S.A. Iasi - } \\
\text { mechanical steps }\end{array}$ & Bahlui & $\begin{array}{l}\text { Suspended solids, } \mathrm{BOD}_{5}, \mathrm{COD}-\mathrm{Cr} \text {, } \\
\text { total nitrogen }\end{array}$ & Insufficient \\
\hline 8 & $\begin{array}{l}\text { Iasi Municipality - local } \\
\text { municipal waste deposit }\end{array}$ & $\begin{array}{l}\text { Bahlui } \\
\text { Vamasoaia } \\
\text { Repedea } \\
\text { Cocaina }\end{array}$ & $\begin{array}{l}\text { Organic matter }\left(\mathrm{BOD}_{5}, \mathrm{COD}-\mathrm{Cr}\right) \text {, } \\
\text { heavy metals, ammonia, } \mathrm{H}_{2} \mathrm{~S}+ \\
\text { sulphides }\left(\mathrm{S}^{2-}\right) \text {, toxics }\end{array}$ & Not treated \\
\hline 9 & $\begin{array}{l}\text { S.C. TERMOELECTRICA } \\
\text { S.A. - CET II Holboca Iasi }\end{array}$ & Bahlui & $\begin{array}{l}\text { Suspended solids, } \mathrm{BOD}_{5}, \mathrm{COD}-\mathrm{Cr} \text {, } \\
\text { fixed residues, sulphides }\left(\mathrm{S}^{2-}\right)+\mathrm{H}_{2} \mathrm{~S}\end{array}$ & Not treated \\
\hline 10 & $\begin{array}{l}\text { R.A. Citadin Iasi - industrial } \\
\text { and municipal waste landfill }\end{array}$ & Bahlui & $\begin{array}{l}\text { Organic matter }\left(\mathrm{BOD}_{5}, \mathrm{COD}-\mathrm{Cr}\right) \text {, } \\
\text { heavy metals, ammonia, sulphides } \\
\left(\mathrm{S}^{2-}\right)+\mathrm{H}_{2} \mathrm{~S} \text {, toxics (or leachate) }\end{array}$ & $\begin{array}{l}\text { Not treated } \\
\text { (in 2009-2010) }\end{array}$ \\
\hline
\end{tabular}

The natural polluting sources of Bahlui surface water are due to (1) precipitations (nitrogen oxides from atmosphere emitted by a flash of lightning, fuel combustion, or washing of rocks, or ashes from uncontrolled vegetation self-burning etc.) introduced directly in natural water resources; (2) ammonia nitrification by nitrosomonas and nitrosococcus microorganisms (bacteria), and of nitrites by nitrobacter; (3) spring source as result of in-deep dissolution in rocks, or nitrates-containing soil erosion etc. [3].

Some diffuse anthropogenic (domestic) pollution sources with decreasing in-time significance in overall water pollution level (Iasi town area) are consisting of [12]: (1) wrong fertilization (in excess) with fertilizer (chemical commercial products) in individual homehouses, or other types of domestic residential locations, and manure (natural product) or compost; (2) not respecting of some important rules of portioning and construction of stables and wells; (3) wrong/poor management of stable refuses (directly storage on soil of animal wastes, manures and wastewaters); (4) inefficient management of rural and urban municipal wastes; (5) infiltrations of wastewaters produced from unstable tight-closing systems or individual toilets, or inexistence of functional wastewater collection and treatment systems.

The evaluated data of selected quality indicators of Bahlui river in the two control sections $\left(C S_{1}\right.$ and $\left.C S_{2}\right)$ at entrance and ending area of Iasi town are presented in Table 5, mainly considering the cumulative organic matters, phosphorus, and nitrogen-based nutrient contents. 
Reffering to nitrates of Bahlui river in Iasi town area, the normalized values had values between $1.50 \mathrm{mg} / \mathrm{L}$ in $C S_{1}$ (2009), and $8.65 \mathrm{mg} / \mathrm{L} \mathrm{NO}_{3}{ }^{-}$in $C S_{2}$ (2010), not exceeding admissible limits. Therefore, the Bahlui river quality is affected by nitrates from domestic and urban WW treatment activities, but in admissible limits, and this effect can not be yet quantified $\left(E S_{i}=9\right.$; Table 6$)$.

Table 5. Average values of quality indicators in the two studied control sections of Bahlui river in Iasi town area (2009-1010) (source: A.N. Apele Romane - Prut-Barlad Waters Basin Mangement Division, and proper analyses of quality indicators for data validation $[15,21])$.

\begin{tabular}{|c|c|c|c|c|c|c|}
\hline \multirow{4}{*}{ Qualityindicators } & \multicolumn{6}{|c|}{ Control sections } \\
\hline & \multicolumn{3}{|c|}{ ValeaLupului-Iasi $\left(\mathrm{CS}_{1}\right)$} & \multicolumn{3}{|c|}{ Holboca - Iasi $\left(\mathrm{CS}_{2}\right)$} \\
\hline & \multicolumn{2}{|c|}{ Normalized value, $[\mathrm{mg} / \mathrm{L}]$} & \multirow{2}{*}{$\begin{array}{l}\mathrm{MAC} \\
{[\mathrm{mg} / \mathrm{L}]}\end{array}$} & \multicolumn{2}{|c|}{ Normalized value, $[\mathrm{mg} / \mathrm{L}]$} & \multirow{2}{*}{$\begin{array}{l}\mathrm{MAC}, \\
{[\mathrm{mg} / \mathrm{L}]}\end{array}$} \\
\hline & 2009 & 2010 & & 2009 & 2010 & \\
\hline $\mathrm{BOD}_{5},\left[\mathrm{mg} \mathrm{O}_{2} / \mathrm{L}\right]$ & 8.88 & 9.88 & 3 & 4.66 & 3.90 & 3 \\
\hline $\mathrm{CCO}-\mathrm{Mn},\left[\mathrm{mg} \mathrm{O}_{2} / \mathrm{L}\right]$ & 14.29 & 18.96 & 5 & 49.20 & 56.40 & 5 \\
\hline Nitrates, $\mathrm{NO}_{3}^{-}$ & 1.50 & 6.30 & 50.0 & 7.89 & 8.65 & 50.0 \\
\hline Nitrites, $\mathrm{NO}_{2}^{-}$ & 0.75 & 0.62 & 0.5 & 0.31 & 0.48 & 0.5 \\
\hline Ammonia, $\mathrm{NH}_{4}^{+}$ & 1.23 & 0.98 & 0.5 & 4.01 & 4.21 & 0.5 \\
\hline Total phosphorus, $\mathrm{P}$ & 0.48 & 0.45 & 0.2 & 0.39 & 0.53 & 0.2 \\
\hline Fixed residues & 887 & 764 & 500 & 618 & 734 & 500 \\
\hline
\end{tabular}

For nitrites, the mediated values are varied between $0.31 \mathrm{mg} / \mathrm{L}$ in $C S_{2}(2009)$ and $0.75 \mathrm{mg} / \mathrm{L} \mathrm{NO}_{2}^{-}$in $C S_{1}(2009)$, exceeding the maximum admissible limit in $C S_{1}\left(2009\right.$, and 2010) but not in $C S_{2}$; the Bahlui water is affected by nitrites from domestic, agricultural and zootechnical activities (Letcani-Iasi) at entrance in Iasi town but under the maximal admissible limit $-1^{\text {st }}$ alert level of potential effects (in 2010) and $2^{\text {nd }}$ intervention level of potential effect (in 2009) $\left(E S_{i}=6\right)$. At the finishing area of Iasi town $\left(C S_{2}\right)$, the Bahlui water quality is affected by nitrites under the maximum admissible limit, with potential effects $\left(E S_{i}=8\right.$ in 2009, and $E S_{i}=7$ in 2010; Table 6) mainly due to domestic and WW treatment activities alongside its watercourse.

The ammonia content exceeded the admissible limits more than 2.0 times in $C S_{1}$ (2010), with maximal exceeding of 8.42 times in $C S_{2}$ (2010), indicating a high affected water quality with lethal effect at long and persistent time exposure of sensitive life forms $\left(E S_{i}=3\right.$; Table 6).

For the mineralization indicator (fixed residue), the Bahlui watercourse is affected over the maximum admissible limit $-1^{\text {st }}$ level of pronounced effects in both $C S_{1}$ and $C S_{2}$ investigated control sections $\left(E S_{i}=6\right.$; Table 6).

Reffering to COD (sum organics' content), the Bahlui watercourse quality is much affected than that of $\mathrm{BOD}_{5}$ especially in $C S_{2}(2010)$, being over the maximum admissible limit, with pronounced effects $\left(E S_{i}=6\right)$, or toxic effects $\left(E S_{i}=5\right.$; Table 6$)$, or posible lethal effects at long and persistent exposure $\left(E S_{i}=3\right.$; Table 6) mainly because of high loads discharged from the accidental-polluting point sources alongside this watercourse, and also urban wastewater treatment plant.

Table 6. Values of $E Q_{i}$ and $E S_{i}$ in the two control sections of Bahlui watercourse in Iasi town area (2009-2010).

\begin{tabular}{|l|c|c|c|c|c|c|c|c|}
\hline \multirow{3}{*}{ Quality indicators, } & \multicolumn{9}{|c|}{ Control section } \\
\cline { 2 - 10 } & \multicolumn{2}{|c|}{$\mathrm{QI}_{1^{-}}$ValeaLupuli-Iasi $\left(\mathrm{CS}_{1}\right)$} & \multicolumn{4}{c|}{$C S_{2^{-}}$Holboca - Iasi $\left(\mathrm{CS}_{2}\right)$} \\
\cline { 2 - 10 } & 2009 & 2010 & 2009 & 2010 & 2009 & 2010 & 2009 & 2010 \\
\hline $\mathrm{BOD}_{5}$ & 2.56 & 3.29 & 5 & 5 & 1.55 & 1.30 & 6 & 6 \\
\hline $\mathrm{CCO}-\mathrm{Mn}$ & 2.86 & 3.78 & 5 & 5 & 9.84 & 11.28 & 3 & 3 \\
\hline Nitrates, $\mathrm{NO}_{3}^{-}$ & 0.03 & 0.13 & 9 & 9 & 0.16 & 0.17 & 9 & 9 \\
\hline Nitrites, $\mathrm{NO}_{2}^{-}$ & 1.50 & 1.24 & 6 & 6 & 0.62 & 0.96 & 8 & 7 \\
\hline Ammonia, $\mathrm{NH}_{4}{ }^{+}$ & 2.46 & 1.96 & 5 & 6 & 8.02 & 8.42 & 3 & 3 \\
\hline Total phosphorus $(\mathrm{P})$ & 2.40 & 2.25 & 5 & 5 & 1.95 & 2.65 & 6 & 5 \\
\hline Fixed residues & 1.77 & 1.53 & 6 & 6 & 1.24 & 1.47 & 6 & 6 \\
\hline Average value: & 1.94 & 2.026 & 5.857 & 6.00 & 3.34 & 3.75 & 5.857 & 5.571 \\
\hline
\end{tabular}


Reffering to the European standard evaluation of water quality indices $\left(W Q I_{i}\right)$, the results presented in Table 7 indicates that $W Q I_{i}$ values, for the two studied control sections of Bahlui watercourse in Iasi town area, varied in range of (57.85 - 64.345), estimating the Bahlui watercourse quality as 'medium', fact that was imposed, or required urgently remediation actions and continuously quality controls (recommendations considered further). In addition, it seems from Table 7 that the water classification of Bahlui river in Iasi town area was of 'medium', requiring urgently remediation actions (as the hydro-ameliorative actions organized in a part of Bahlui watercourse, i.e. between bridges of Stone Bridge (in Romanian: Podul de Piatra) and 'Metalurgica' Bridge (in Romanian: Podul cart. Metalurgie) - Holboca Iasi (initiated in 2011, and finished in 2013/2014) in order to perform until the end of time period (2015 - 2018) a quoted water classification of 'good', as it was imposed for all Romanian hydrographical basins (total number of $11 \mathrm{h.b}$.) in the $7^{\text {th }}$ Action Plan, especially for natural watercourses protection and conservation [17].

Table 7. Comparative results for $Q I_{W}$ (Eq. (1)), and $W Q I_{i}$ (Eq. (2)) and its corresponding water classification.

\begin{tabular}{|c|c|c|c|c|c|}
\hline Control section & Year & $\begin{array}{c}\text { Average } Q I_{W} \\
\text { (Eq.1) }\end{array}$ & $\begin{array}{c}\text { Normalized } Q I_{W} \\
\text { (considering each } i \\
\text { indicator weights) }\end{array}$ & $\begin{array}{c}W Q I_{i} \\
\text { (Eq.2) }\end{array}$ & $\begin{array}{c}\text { Water classification } \\
\text { (reffering to EU Standards) }\end{array}$ \\
\hline \multirow{2}{*}{$\mathrm{CS}_{1}$} & 2009 & 1.94 & 2.058 & 64.345 & medium \\
\cline { 2 - 6 } & 2010 & 2.026 & 2.241 & 57.850 & medium \\
\hline \multirow{2}{*}{$\mathrm{CS}_{2}$} & 2009 & 3.34 & 4.199 & 53.893 & medium \\
\cline { 2 - 6 } & 2010 & 3.75 & 4.625 & 63.088 & medium \\
\hline
\end{tabular}

In this context, by further application of alternative methodology of global pollution index for environmental impact assessment it is possible to estimate that the real situation corresponds to a Bahlui watercourse quality modified by the domestic and urban WW treatment with generation of discomfort effects in $C S_{1}$ control section (entrance in Iasi town area, Valea Lupului area) with $I_{G P}^{*}$ values of 2.80 (2009), or 2.929 (2010) (Table 6), and in $C S_{2}$ control section (downstream of urban Dancu wastewater treatment plant) with $I_{G P}^{*}$ values of 3.030 (2009), or 3.196 (2010) (Table 8), according with the quality indicators data reported by the environmental regulatory authority for this zone. In addition, it seems that the Bahlui water quality is already affected at entrance in Iasi town area $\left(C S_{1}\right)$, and flowing through this town area adding some new increasing polluting loads in its water mass, fact that is evident in the selected results (normalized data) in $C S_{2}$ control section.

Table 8. $E S_{i}$ and $I_{G P}^{*}$ values, associated with estimation of real water pollution status of Bahlui river in the investigated control sections $\left(C S_{1}\right.$ and $\left.C S_{2}\right)$.

\begin{tabular}{|l|c|c|c|c|c|c|c|}
\hline \multirow{2}{*}{ Control Sections } & \multicolumn{3}{|c|}{2009} & \multicolumn{3}{c|}{2010} & $\begin{array}{c}\text { Real pollution status of Bahlui } \\
\text { river }\end{array}$ \\
\cline { 2 - 7 } & $\overline{E S_{W}{ }^{2}}$ & $E S_{W}$ & $I_{G P}^{*}$ & ${\overline{E S_{W}}}^{2}$ & $E S_{W}$ & $I^{*}{ }_{G P}$ & \\
\hline $\begin{array}{l}C S_{1} \text { - Valea } \\
\text { Lupului-Iasi }\end{array}$ & 34.143 & 5.857 & 2.929 & 35.714 & 6.00 & 2.800 & $\begin{array}{c}\text { Water quality modified by all } \\
\text { domestic and WW treatment } \\
\text { activities, with generation of } \\
\text { discomfort effects }\end{array}$ \\
\hline$C S_{2}$ - Holboca-Iasi & 33.00 & 5.857 & 3.030 & 31.286 & 5.571 & 3.196 & $\begin{array}{c}\text { Water quality modified by all } \\
\text { domestic and WW treatment } \\
\text { activities, with stress producing } \\
\text { against life forms }\end{array}$ \\
\hline
\end{tabular}

As final result of this real pollution status estimation due to domestic and urban wastewater treatment activities against aquatic environment in Bahlui River (Iasi town area), it is recommended the implementation of some remediation actions, but also preventive measures, associated with permanent monitoring of organic matter content, and also phosphorus and nitrogen-based nutrients content in all existing strategic control sections, for identification of any increasing exceeding of different potential polluting species, or pollution episodes, notreported by polluters to the local environmental regulators.

\section{CONCLUSIONS}

Some raported data from the water regulatory authority of Bahlui river (A.N. Apele Romane - A.B.A. PrutBarlad), or proper laboratory analyses (for validation of some reported data of water regulatory authority) concerning the total organic matter $\left(\mathrm{COD}, \mathrm{BOD}_{5}\right)$, total phosphorus (total $\left.\mathrm{P}\right)$ and nitrogen-based nutrient content 
(i.e. ammonia- $\mathrm{NH}_{4}{ }^{+}$, nitrates- $\mathrm{NO}_{3}{ }^{-}$, nitrites- $\mathrm{NO}_{2}{ }^{-}$) are processed for water quality classification (using EU standards and a local proposed evaluation scale), and its real water pollution status due to domestic and urban wastewater treatment activities in Iasi town area (as an environmental cumulative impact evaluation due to domestic and treatment activities).

Some quality indicators were exceeded the maximum admissible limits in each investigated year (2009 and 2010), and the corresponding surface water category was of 'degraded' for $\mathrm{BOD}_{5}$ (i.e. max. $62.5 \mathrm{mg} \mathrm{O}_{2} / \mathrm{L}$, referring to standard M.A.C. $=25 \mathrm{mg} \mathrm{O} / \mathrm{L}$ ) and total phosphorus (i.e. max. 0.67 , referring to standard M.A.C. $=0.5 \mathrm{mg} / \mathrm{L}$ ), and the $\mathrm{III}^{\text {rd }}$ category for fixed residues (i.e. max. $1,508 \mathrm{mg} / \mathrm{L}$, referring to standard M.A.C. $=500 \mathrm{mg} / \mathrm{L}$ ), for dissolved oxygen in $\mathrm{CS}_{2}$ (i.e. $\mathrm{min} .2 .3 \mathrm{mg} \mathrm{O}_{2} / \mathrm{L}$, referring to standard M.A.C. $=\min 4.0-$ $6.0 \mathrm{mg} \mathrm{O} / 2$ for life forms development) and for ammonia in $\mathrm{CS}_{2}$ (i.e. $\max .11 .0 \mathrm{mg} \mathrm{NH}_{4}{ }^{+} / \mathrm{L}$, referring to standard M.A.C. $=2 \mathrm{mg} \mathrm{NH}_{4}+/ \mathrm{L}$ ). The other common quality indicators were included in the $\mathrm{I}^{\text {st }}$ and $\mathrm{II}^{\text {nd }}$ quality category, corresponding to admissible limits in surface waters.

The estimated Bahlui standard water quality classification in Iasi town is quoted as 'medium' ( $W Q I=53.893$ 64.345), fact that required urgently remediation actions, and also continuous controls until obtaining of at least 'good' quality (final legislative imposed deadline time period of 2015-2018).

In general, the surface water quality is expressed by values of quality indices $(Q I)$ varying in range of (1.94-3.75) in the evaluated time period (higher in 2010 related to 2009), or evaluation scores varying in range of 5.571-6.00 (higher in 2010 referring to 2009).

The water pollution status of Bahlui river in Iasi town area is over the maximum admissible limits in evaluated time period (i.e. alert, sometime intervention level, caused by specific potential polluting species), producing potential stress effects against life forms, and potential risks can be manifested, fact expressed by the calculated values of water quality indices $(Q I)$ and evaluation scores $(E S)$, and also the global pollution index $\left(I^{*}{ }_{G P}\right)$ which varies in range of $(2.80-3.196)$.

The $I_{G P}^{*}$ values estimate the real pollution status which corresponds to 'surface water modified by the domestic and urban $W W$ treatment with generation of discomfort effects in $C S_{I}$ control section (entrance in Iasi town area, Valea Lupului-Iasi), and with stress producing against life forms in $C S_{2}$ control section (downstream of urban Dancu wastewater treatment plant) (2009-2010).

These data indicate the necessity of permanent water monitoring in the existing control sections of Bahlui watercourse in Iasi town area for identification of any in-time increasing values, or exceeding of maximum admissible limits, or different pollution episodes, non-reported by polluters to the local environmental regulators.

\section{REFERENCES}

[1] http://www.anpm.ro (02.12.2015).

[2] Zaharia, C., Elements of aquatic environment chemistry (in Romanian), Ed. Performantica, Iasi, 2011.

[3] Teodosiu, C., Challenges for integrated water resources management in Romania, Environmental Engineering and Management Journal, vol. 6, 2007, p. 363-374.

[4] Teodosiu, C., Barjoveanu, G., Teleman, D., Sustainable water resources management I. River basin management and the EC water framework directive, Environmental Engineering and Management Journal, vol. 2, no. 4, p. 377-394.

[5] Barjoveanu, G., Cojocariu, C., Robu, B., Teodosiu, C., Integrated assessment of wastewater treatment plants for sustainable river basin management, Environmental Engineering and Management Journal, vol. 9, no. 9, 2010, p. 1251-1258.

[6] Teodosiu, C., Cojocariu, C., Musteret, C.P., Dascalescu, I.G., Caraene, I., Assessment of human and natural impacts over water quality in the Prut River Basin, Romania, Environmental Engineering and Management Journal, vol. 8, no. 6, p. 1439-1450.

[7] Barjoveanu, G., Comandaru, I.M., Rodriguez-Garcia, G., Hospido, A., Evaluation of water services system through LCA. A case study for Iasi City, Romania, The International Journal of Life Cycle Assessment, vol. 19, no. 2, 2014, p. 449-462.

[8] Teodosiu, C., Robu, B., Cojocariu, C., Barjoveanu, G., Environmental impact and risk quantification based on selected water quality indicators, Natural Hazards, vol. 75, no. 1, 2015, p. 89-105. 
[9] Dernbach, J.C., Mintz, J.A., Environmental laws and sustainability: an introduction, Sustainability, vol. 3, 2011, p. 531-540.

[10] Benchea, R.E., Cretescu, I., Macoveanu, M., Monitoring of water quality indicators for improving water resources management of Bahlui river, Environmental Engineering and Management Journal, vol. 10, no. 3, 2011, p. 327-332.

[11] Cretescu, I., Craciun, I., Benchea, R.E., Kovács, Z., Iavorschi, A., Sontea, V., Macoveanu, M., Development of an expert system for surface water quality monitoring in the context of sustainable management of water resources, Environmental Engineering and Management Journal, vol. 12, no. 8, 2013, p. 1721-1734.

[12] Zaharia, C., Evaluation of water pollution status in Siret Hydrographical Basin (Suceava Region) due to agricultural activities, Chemistry Journal of Moldova. General, Industrial and Ecological Chemistry, vol. 9, no. 1,2014, p. 42-52.

[13] Teodosiu, C., Cojocariu, C., Musteret, C.P., Dascalescu, I.G., Caraene, I., Assessment of human and natural impacts over water quality in the Prut River Basin, Romania, Environmental Engineering and Management Journal, vol. 8, no. 3, 2010, p. 1439-1450.

[14] Zaharia, C., Radu, I., Control study of Siret River quality in Pascani county area and estimation of its pollution level, Acta Chemica Iasi, vol. 21, no. 2, 2013, p. 119-136.

[15] Zaharia, C., Teslaru, M.I., Control and analysis of some water quality indicators of Bahlui River in Iasi county area (spring season), The Bulletin of the Polytechnic Institute from Iasi, series: Chemistry and Chemical Engineering Section, vol. LVIII(LXII), no. 2, 2012, p. 69-79.

[16] Danalache, E., Zaharia, C., Control of some quality indicators of Prut River in two control sections (Radauti and Darabani) (spring season), Scientific papers (Lucrari stiintifice), series: Horticulture, vol. 56, no. 2, 2013 , p. 531-536.

[17] Musteret, C.P., Fighir, D., Gavrilescu, D., Zaharia, C., Teodosiu, C., Water and wastewater treatment: practice applications (in Romanian), Ed. Politehnium, Iasi, 2014.

[18] Zaharia, C., Evaluation of environmental impact produced by different economic activities with the global pollution index, Environmental Science and Pollution Research, vol. 19, no. 6, 2012, p. 2448-2455.

[19] Popa, C., Cojocaru, C., Macoveanu, M., Geometrical Correlation method for global estimation of the ecosystem state, Environmental Engineering and Management Journal, vol. 4, no. 4, 2005, p. $437-447$.

[20] Macoveanu, M., Methods and techniques of ecological impact assessment (in Romanian), Ed. Ecozone, $2^{\text {nd }}$ ed., Iasi, 2005.

[21] http://www.apeprut.ro (02.12.2015).

[22] Sanchez, E., Colmenarejo, M.F., Vicente, J., Rubio, A., Garcia, M.G., Travieso, L., Borja, R., Use of the water quality index and dissolved oxygen deficit as simple indicators of watersheds pollution, Ecological Indicators, vol. 7, 2007, p. 315-328.

[23] Pesce, S.F., Wunderlin, D.A., Use of water quality indices to verify the impact of Cordoba City (Argentina) on Suquia River, Water Res., vol. 34, 2000, p. 2915-2926. 